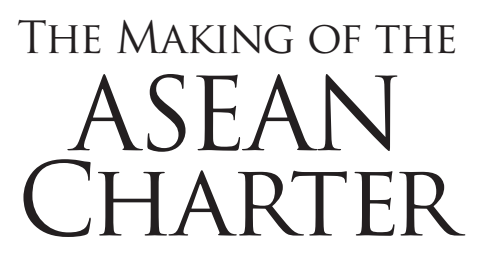


This page intentionally left blank 


\section{THE MAKING OF THE}

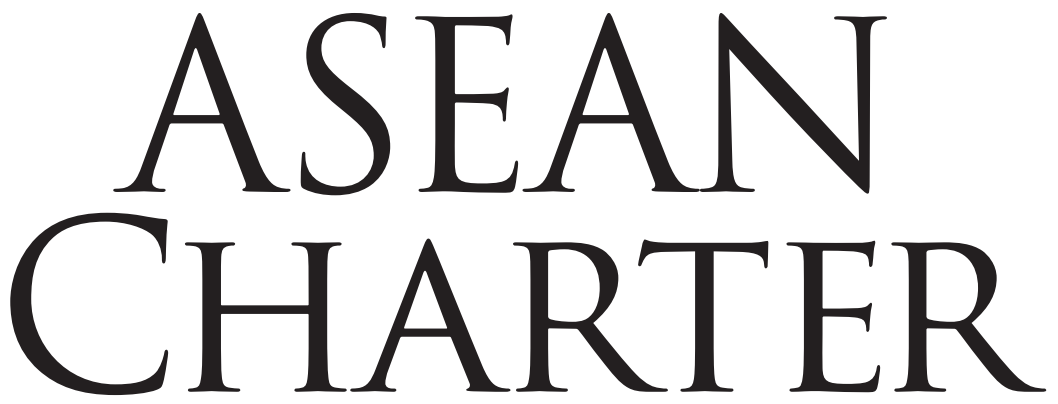

\section{EDITORS}

TOMMY KOH

Ambassador-At-Large, Singapore

ROSARIO G MANALO

European Studies Program, Ateneo de Manila University, The Philippines

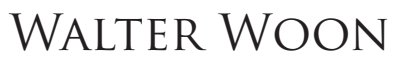

Attorney-General, Singapore 
Published by

World Scientific Publishing Co. Pte. Ltd.

5 Toh Tuck Link, Singapore 596224

USA office: 27 Warren Street, Suite 401-402, Hackensack, NJ 07601

UK office: 57 Shelton Street, Covent Garden, London WC2H 9HE

\section{Library of Congress Cataloging-in-Publication Data}

The making of the ASEAN Charter / edited by Tommy Koh, Rosario G Manalo, and

Walter Woon.

p. cm.

ISBN-13 978-981-283-390-7

ISBN-10 981-283-390-0

I. Koh, Tommy T. B. (Tommy Thong Bee), 1937- $\quad$ II. Manalo, Rosario G.

III. Woon, Walter C. M. IV. ASEAN.

2009000844

\section{British Library Cataloguing-in-Publication Data}

A catalogue record for this book is available from the British Library.

Copyright $@ 2009$ by World Scientific Publishing Co. Pte. Ltd.

All rights reserved. This book, or parts thereof, may not be reproduced in any form or by any means, electronic or mechanical, including photocopying, recording or any information storage and retrieval system now known or to be invented, without written permission from the Publisher.

For photocopying of material in this volume, please pay a copying fee through the Copyright Clearance Center, Inc., 222 Rosewood Drive, Danvers, MA 01923, USA. In this case permission to photocopy is not required from the publisher.

In-house Editor: Juliet Lee Ley Chin

Printed in Singapore. 


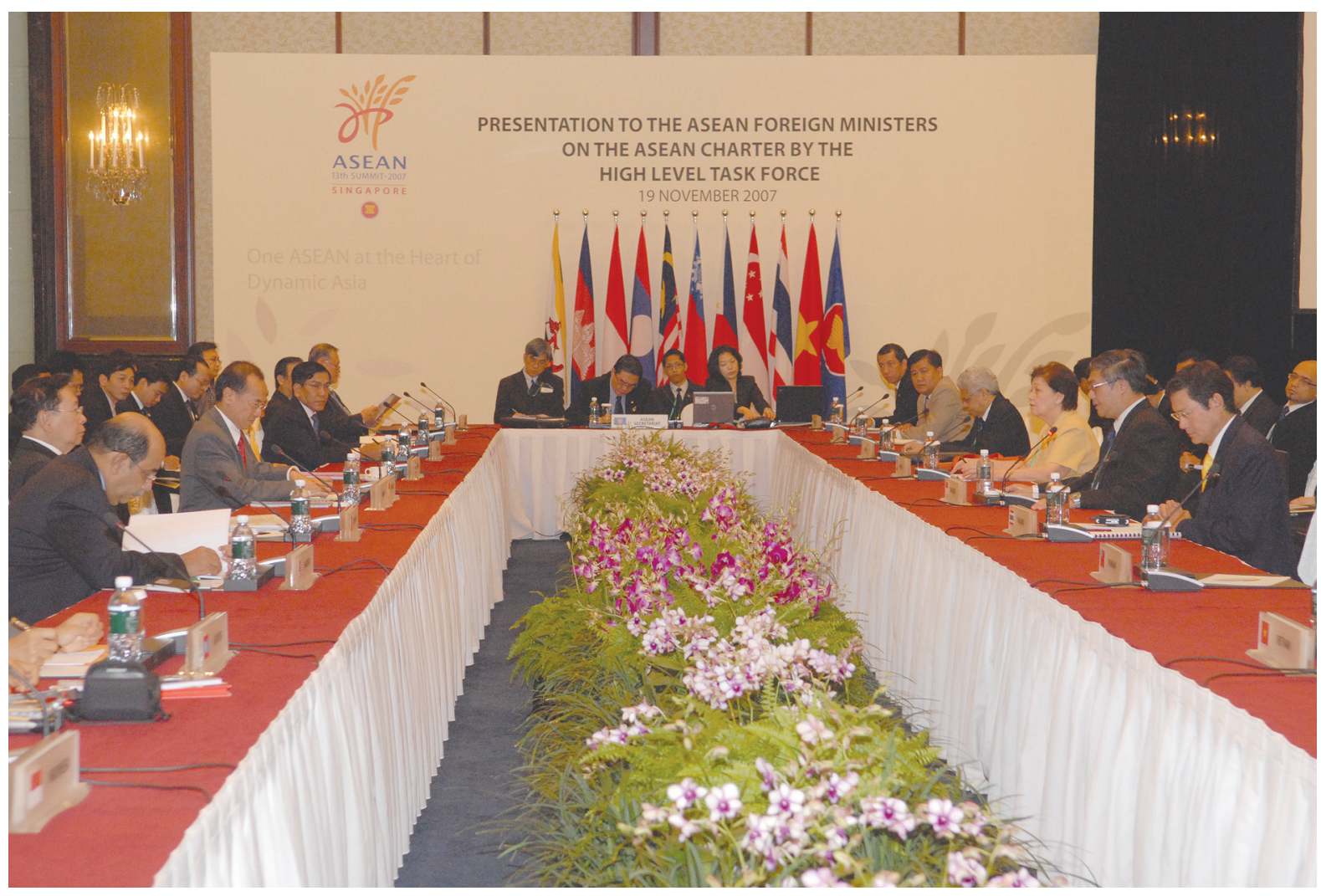

Presentation of the ASEAN Charter to the ASEAN Foreign Ministers 


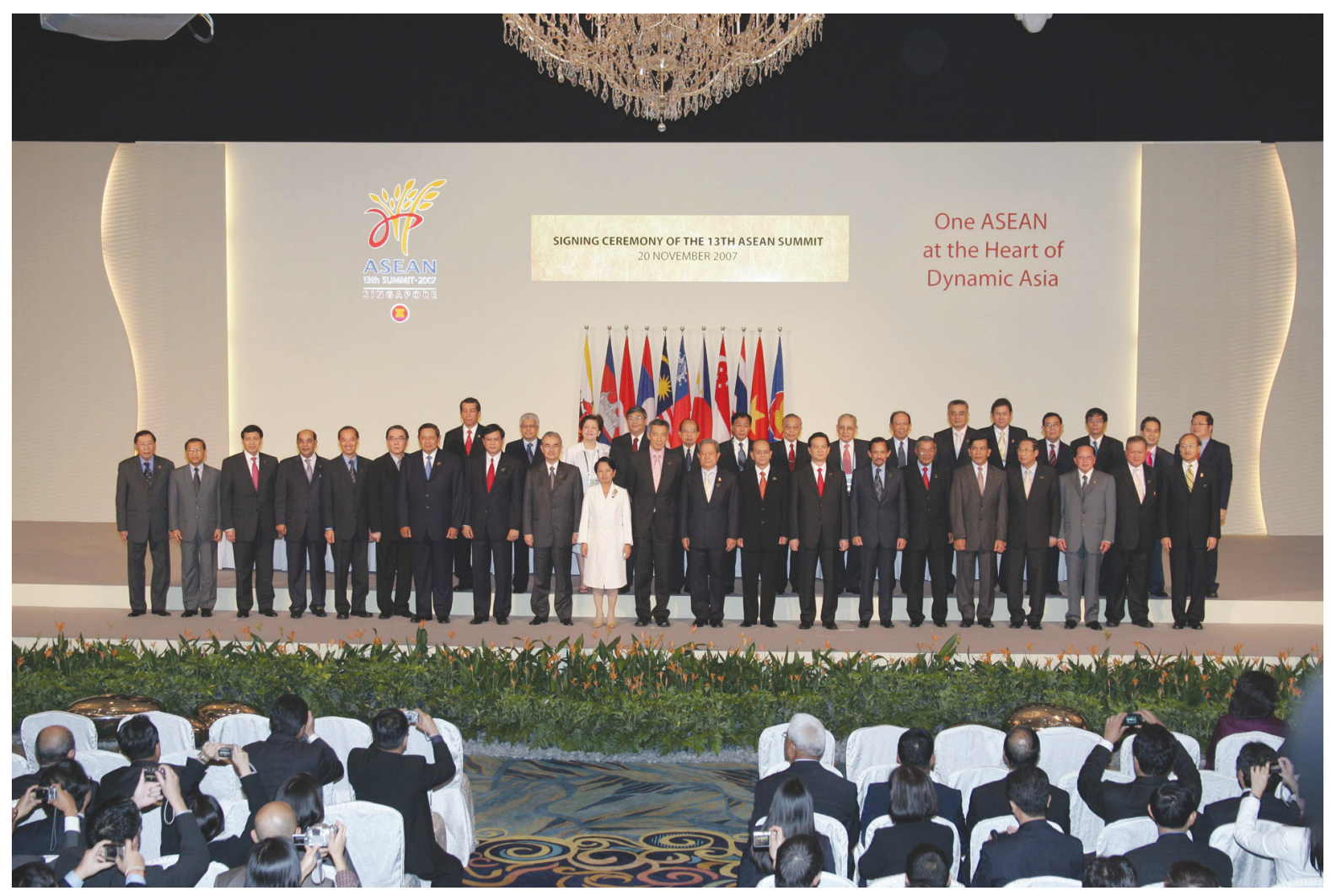

ASEAN Leaders and Ministers with Members of the EPG and the HLTF 


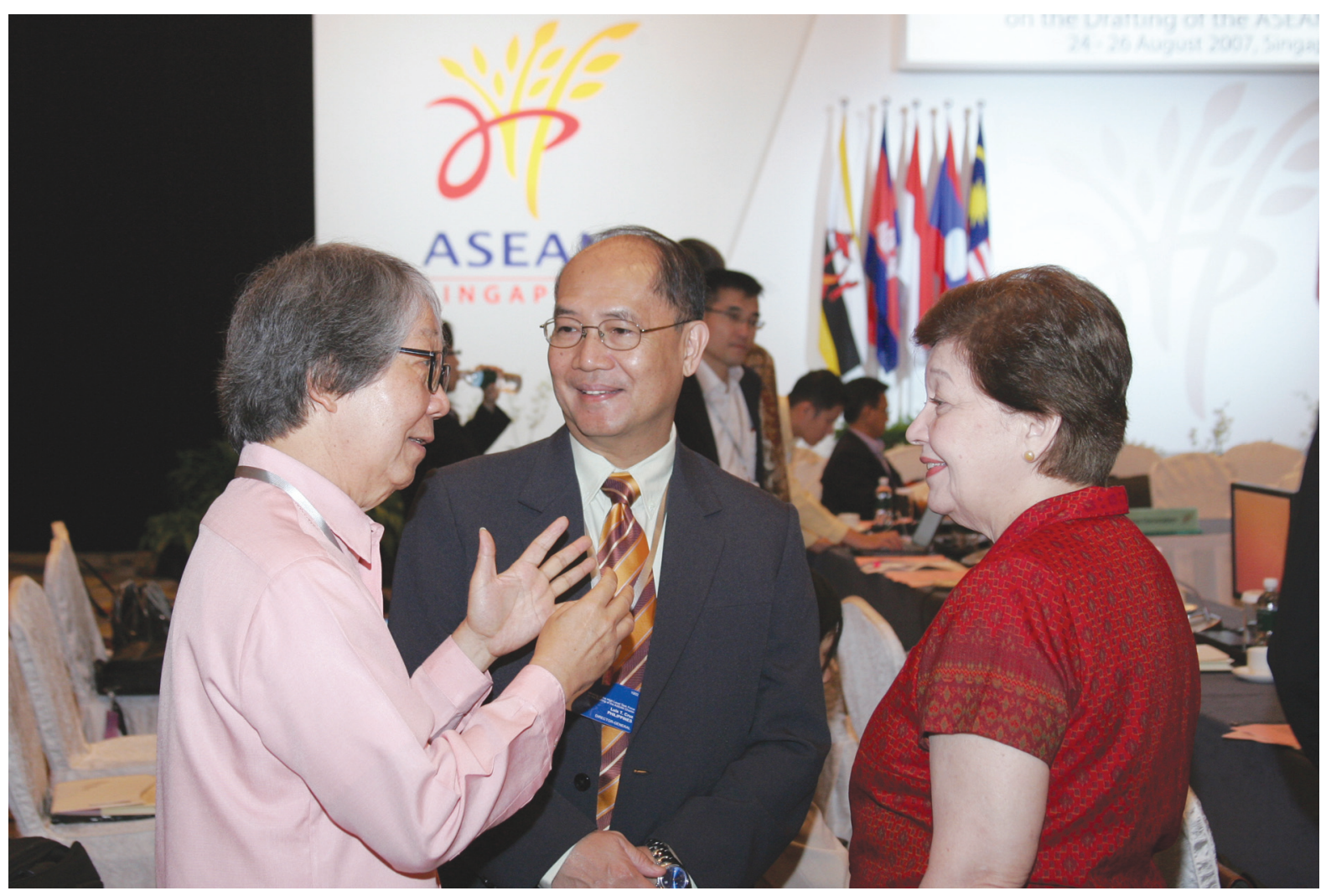

(From left to right) Tommy Koh, Luis T Cruz and Rosario Gonzalez-Manalo 


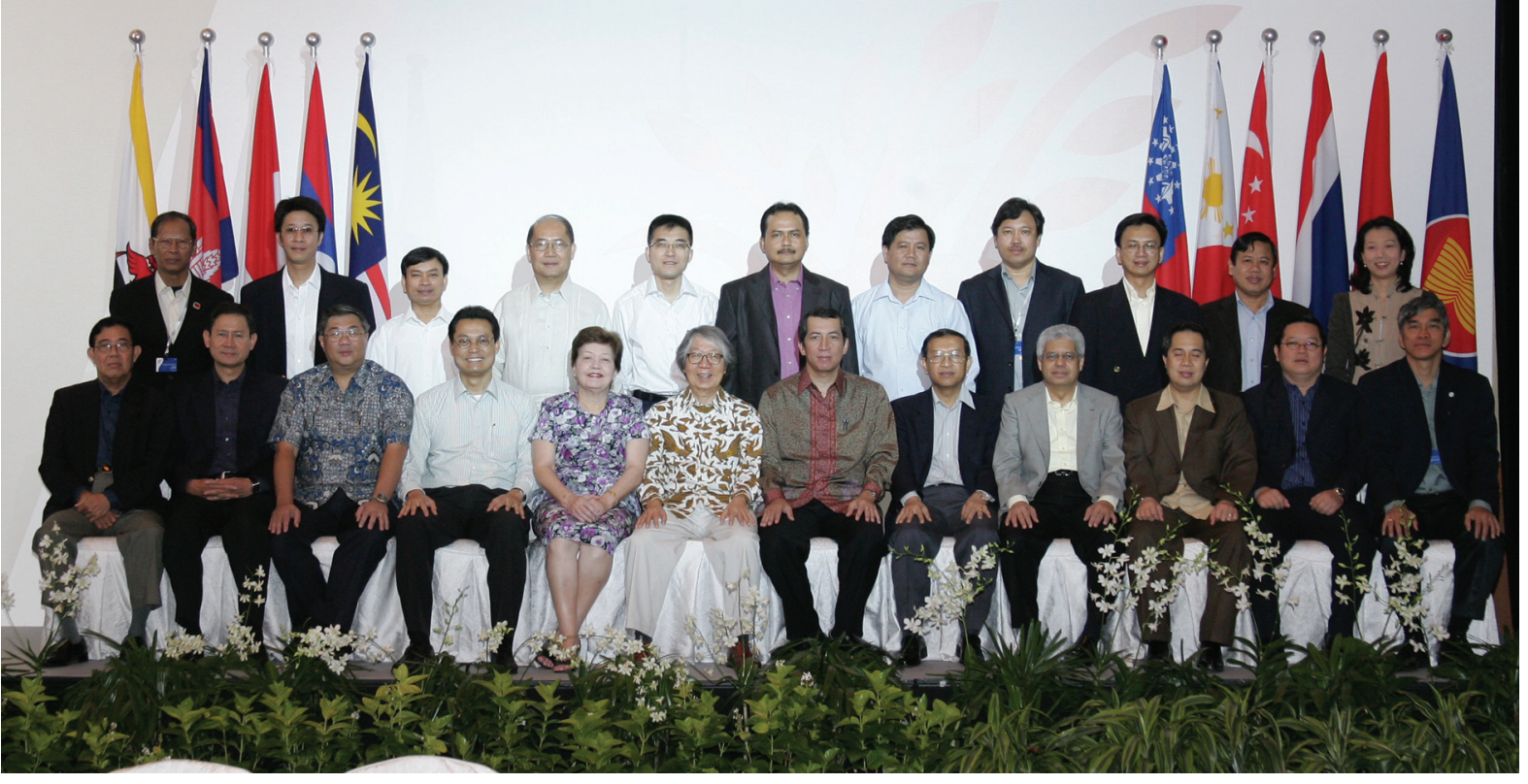

HLTF Members with their Assistants 


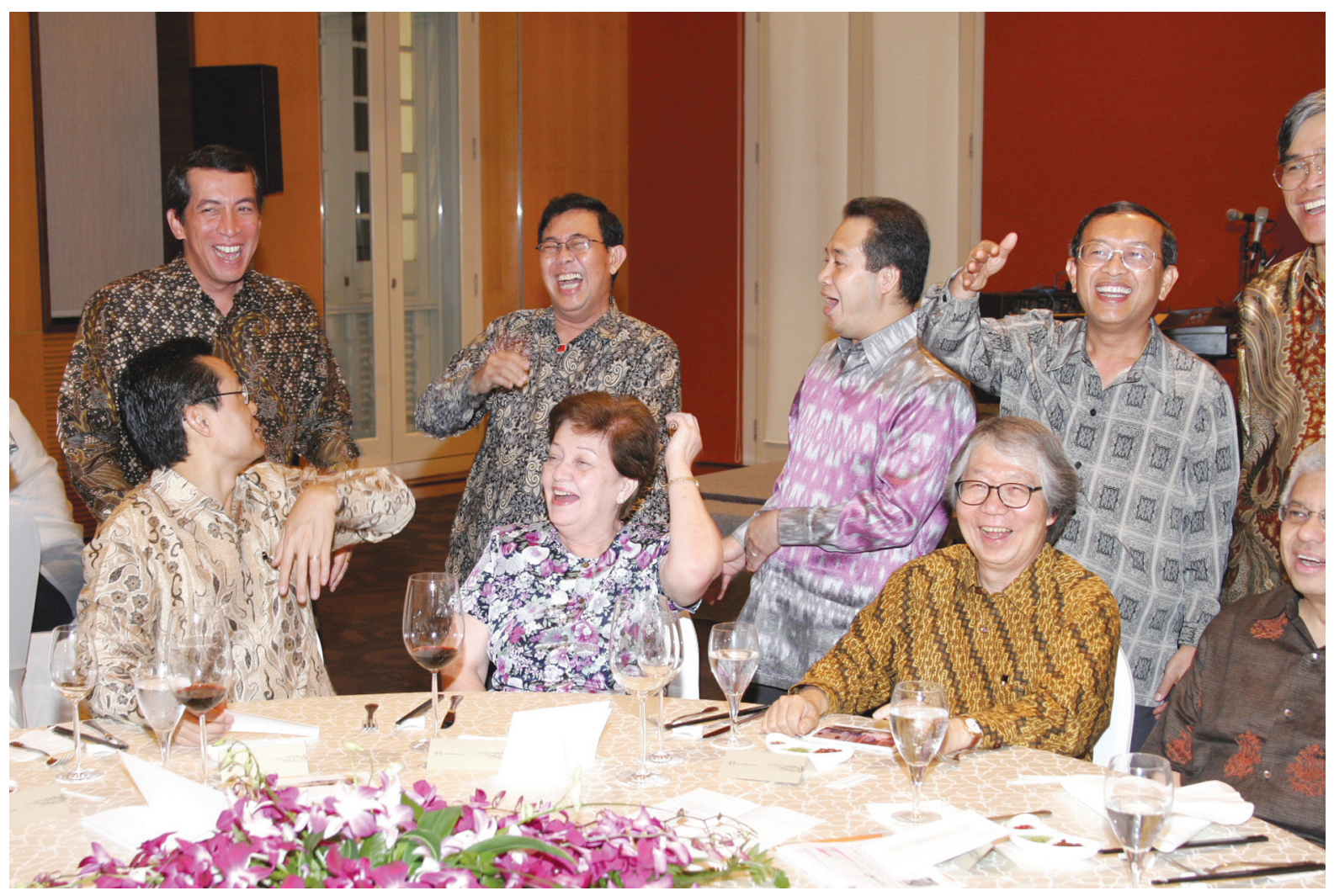

HTLF Members Sharing a Good Laugh over Dinner in Singapore 


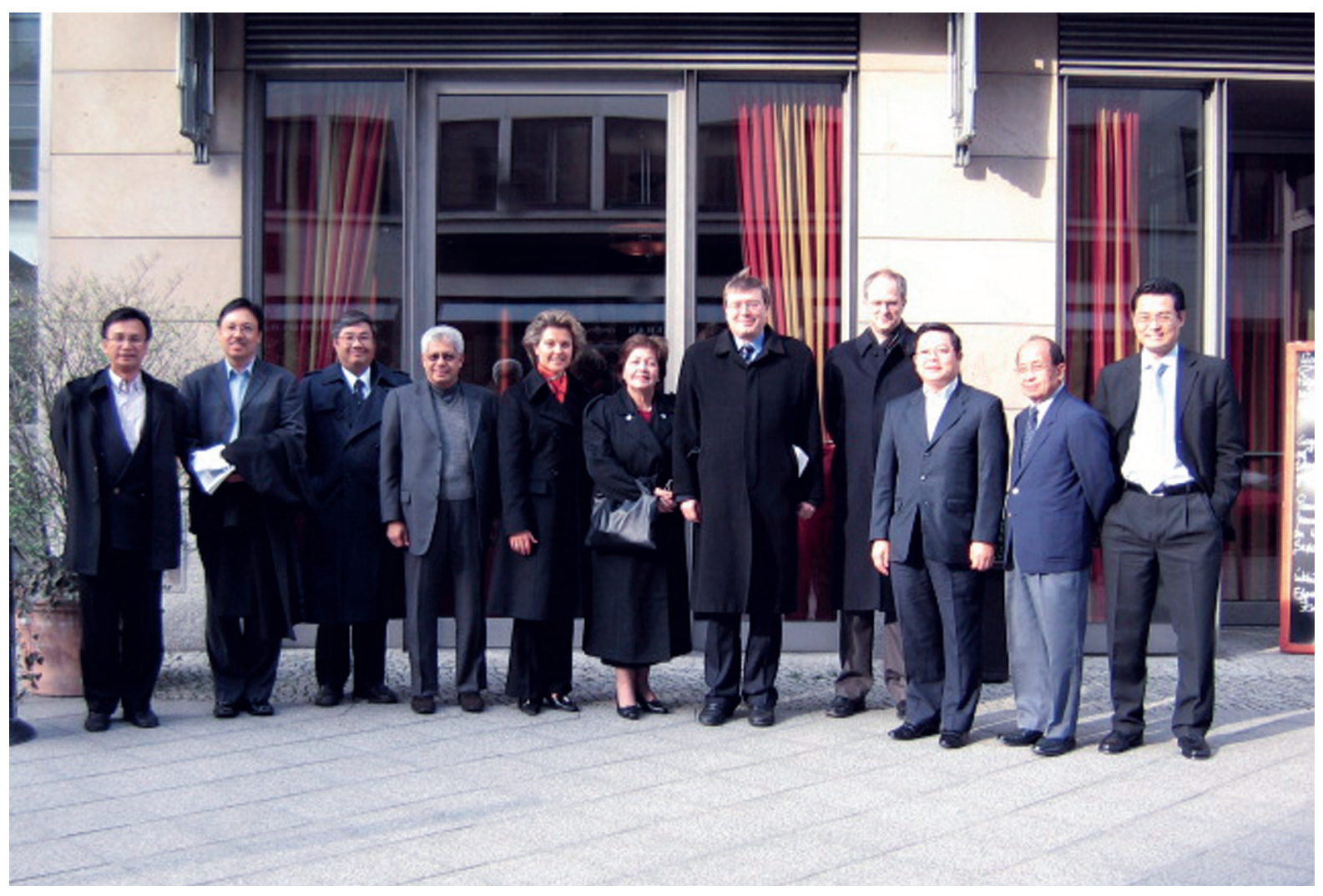

Members of the EPG and HLTF on a Study Visit to Berlin 


\title{
Contents
}

\author{
$\boldsymbol{X V} \quad$ Foreword \\ Dr Surin Pitsuwan, Secretary-General ASEAN \\ xix Preface
}

xxiii Acknowledgements

$x x y \quad$ List of Abbreviations

\section{Chapter 1}

Heart Labour

Pengiran Dato Paduka Osman Patra, Permanent Secretary, Prime Minister's Office, Brunei Darussalam

\section{Chapter 2}

Facing Unfair Criticisms

Tan Sri Ahmad Fuzi bin Abdul Razak, Ambassador-At-Large,

Ministry of Foreign Affairs, Malaysia

\section{Chapter 3}

The Jewel in My Crown

Aung Bwa, Director-General (Rtd.) ASEAN-Myanmar,

Ministry of Foreign Affairs, Union of Myanmar

\section{Chapter 4}

Drafting ASEAN's Tomorrow: The Eminent Persons

Group and the ASEAN Charter

Rosario Gonzalez-Manalo, Special Envoy of the President for the ASEAN Charter, Republic of the Philippines 


\section{Chapter 5}

The Negotiating Process

Tommy Koh, Ambassador-At-Large, Ministry of Foreign Affairs, Singapore

\section{Chapter 6}

The ASEAN Charter Dispute Settlement Mechanisms Walter Woon, Attorney-General, Singapore

\section{Chapter 7}

The Thai Perspective

Pradap Pibulsonggram, Deputy Permanent Secretary,

Ministry of Foreign Affairs, Kingdom of Thailand

\section{Chapter 8}

The Making of the ASEAN Charter in My Fresh Memories

Nguyen Trung Thanh, Ambassador, The Socialist

Republic of Vietnam in Singapore

\section{Chapter 9}

At Close Quarters with the Drafting of the ASEAN Charter

Ong Keng Yong, Ambassador-At-Large, Ministry of Foreign Affairs, Singapore

\section{Chapter 10}

\section{In Defence of the ASEAN Charter}

Termsak Chalermpalanupap, Special Assistant to ASEAN Secretary-General

\section{Chapter 11}

A Long Journey

Dian Triansyah Djani, Director-General for ASEAN Cooperation, Department of Foreign Affairs, Republic of Indonesia

\section{Chapter 12}

A Personal Reflection Kao Kim Hourn, Secretary of State, Ministry of Foreign Affairs and International Cooperation of Cambodia 


\section{Chapter 13}

A New Turning Point in the Relations Among the Southeast Asian States

Bounkeut Sangsomak, Vice-Minister of Foreign Affairs of the Lao People's Democratic Republic

\section{Annex 1}

Charter of the Association of Southeast Asian Nations

\section{Annex 2}

ASEAN Sectoral Ministerial Bodies

$201 \quad$ Annex 3

Entities Associated with ASEAN

205 Annex 4

ASEAN Flag

207 Annex 5

ASEAN Emblem

209 Annex 6

List of Members of the High Level Task Force

$211 \quad$ Annex 7

List of HLTF Meetings 
This page intentionally left blank 


\section{Foreword}

ASEAN has come a long way in the 41 years since the signing of the Bangkok Declaration in 1967 where the five founding member states of ASEAN (Indonesia, Malaysia, the Philippines, Singapore and Thailand) signed a political document announcing the aspiration of the five senior Ministers of the five Southeast Asian governments to work together under ASEAN. In the last 41 years, ASEAN has grown from a family of five to ten, and the ten countries are now cooperating and integrating on more areas than ever before. The ASEAN Charter has given us new impetus for further integration and growth, and will carry us forward for generations to come.

The ASEAN Charter is a precious gift to the peoples of Southeast Asia. The Charter would not have been possible without the endorsement of the ASEAN Leaders and work of the drafters of the ASEAN Charter - the High Level Task Force on the Drafting of the ASEAN Charter, the drafters of the Terms of Reference of the ASEAN Human Rights Body, and the other supplementary agreements. The Eminent Persons Group on the ASEAN Charter also gave us valuable recommendations. The High Level Task Force on the Drafting of the ASEAN Charter has contributed to the body of knowledge that will go down in the history of the region, for opening up new possibilities for ASEAN. 
The Charter spells out our vision for the future, our commitment to become a people-oriented and regional grouping that is united by a common desire to live in a region of lasting peace, security and economic growth, shared prosperity and social progress. The ASEAN Community will be underpinned by the values of good governance and rule of law as well as the respect for and protection of human rights and fundamental freedoms of our peoples. The ASEAN Charter has also created a new legal and institutional framework with a legal personality and improved decision-making mechanisms to carry out our work.

I have already witnessed some of the implications that the ASEAN Charter have on my work in the first year as the Secretary-General of ASEAN. The "little green book" is indispensable in my dealings with people, who range from the Leaders of the world's greatest superpowers, heads of multilateral institutions, businesses, banks, religious leaders, academia, students, the media, Parliamentarians and civil society. These people come from the ASEAN region as well as from countries with whom ASEAN has yet to establish formal relations. The ASEAN Charter has allowed me to explain issues more clearly to our friends and partners, who support and share the same aspirations, and would like to contribute to our region's future. It has helped ASEAN articulate our values, purposes, visions and foundations on which we are built and our desire to build a regional identity.

The ASEAN Charter has paved the way for ASEAN's stakeholders to build coalitions to help the region grow to embrace the future. It has laid the ground work for the partnerships we will forge with all our stakeholders, from 
different countries and industry sectors, between government and inter-governmental organisations, businesses, academia, civil society, and others, to create a vibrant and integrated Southeast Asia. It is now up to the stakeholders of ASEAN to take up the challenge of regional integration to respond creatively to globalisation and the opportunity to improve our lives. Although many challenges lie ahead, the ASEAN Charter gives us hope, purpose, and importantly, a framework of action for all the peoples of ASEAN.

This book provides insights into the making of the Charter and background of the deliberations on the range of issues that are so pertinent for the region's future. It will help us develop a perspective of the intent of some of the provisions in the Charter.

As ASEAN celebrates the Charter's full ratification by all ASEAN member states and the entry into force this December, I am most grateful to the contributors of this volume who have helped to shed light into the inspiration and guiding principles of the drafting of the ASEAN Charter. This, in turn, will help future generations of the people of ASEAN to appreciate not only the text of the Charter, but also the spirit of our basic document. The more we understand and appreciate what went into the drafting of the Charter, the more we will respect and live our life under its guidance. Our collective endeavours to build the ASEAN Community will certainly benefit from the collective memories and insights contained in this book. And that is nothing less than an intellectual legacy for our posterity.

Surin Pitsuwan Secretary-General of ASEAN Jakarta 
This page intentionally left blank 


\section{Preface}

"Your old men shall dream dreams, your young men shall see visions"

At the $11^{\text {th }}$ ASEAN Summit in Kuala Lumpur in 2005, the Leaders of ASEAN tasked the Eminent Persons Group (EPG) on the ASEAN Charter to propose major steps that could be taken to achieve an ASEAN Community. The EPG was enjoined to be "bold and visionary". The EPG Report was presented to the Leaders at the $12^{\text {th }}$ ASEAN Summit in Cebu on 12 January 2007. The following day the Cebu Declaration on the Blueprint of the ASEAN Charter was issued. The High Level Task Force (HLTF) for the Drafting of the ASEAN Charter received its mandate on the same day. That mandate came with a strict timetable: have the Charter ready for signature at the $13^{\text {th }}$ ASEAN Summit in Singapore.

It is of course a pleasant task to dream dreams and see visions. The process of actually translating the dreams and visions into practical reality requires much more than idealism and a magic wand. In the case of the ASEAN Charter, it took 11 months of hard work and hard negotiation. The work went on literally to the last minute, ending at the stroke of midnight on the final day of the final meeting of the HLTF in Vientiane. 
This is not meant as a textbook interpreting the Charter. It is a record of the impressions of the drafting process by members of the HLTF. Each of the contributors has focused on a different aspect of the drafting; each brings a unique perspective on the process. In his first masterwork Rashomon, the great Japanese film director Kurosawa Akira told the story through the various viewpoints of the different characters. The story of the creation of the ASEAN Charter is told in the same manner in this book.

We have the contributions of the two chairpersons of the HLTF, Ambassador Rosario Manalo of the Philippines and Ambassador Tommy Koh of Singapore. They provide the insights of the two personalities who steered the HLTF in their work. ASEAN Secretary-General Ong Keng Yong shares his unrivaled experience of how ASEAN works in practice. Dr Termsak Chalermpalanupap (the Secretary-General's special assistant and resource person to the HLTF) puts the Charter in its proper historical and political perspective. Each of the other contributors - Director-General Aung Bwa of Myanmar, Pengiran Dato Paduka Osman of Brunei, Tan Sri Ahmad Fuzi of Malaysia, Ambassador Nguyen Trung Thanh of Vietnam, Ambassador Pradap Pibulsonggram of Thailand, DirectorGeneral Dian Triansyah Djani of Indonesia, Secretary of State Kao Kim Hourn of Cambodia and Vice-Minister Bounkeut Sangsomak of the Lao People's Democratic Republic - offers his own unique and interesting view of the drafting process. When Ambassador Tommy Koh took over as Chairman of the HLTF in August 2007, Ambassador Walter Woon was entrusted with the leadership of the Singapore delegation. Rather than overlap what Ambassador Koh has so clearly set 
out in his essay, Ambassador Woon has confined himself to the most legalistic aspect of the Charter, the dispute settlement mechanisms. It is hoped that this collection of essays will enable students of ASEAN to better understand the way the Charter came to be as it is, warts and all.

The ASEAN Charter was not meant to be carved in stone, to stand unchanged for all eternity. ASEAN will evolve and the Charter will evolve with the organisation. What one sees today is a finely-balanced document taking into account the different perspectives, interests and concerns of the ten member states. Of course it could be better drafted, the phrasing could resound more, and there could be a greater dose of idealism and less of down-to-earth practicality; but what multilateral document could escape such criticisms? The important thing is that the Charter provides a practical framework for the functioning of ASEAN.

It is said that a camel is a horse designed by a committee. The ASEAN Charter is the diplomatic equivalent of a camel. It may not have the good looks of a thoroughbred, but the camel is a perfectly good and reliable animal. When the terrain is tough and dry, a camel will survive trials that would kill the toughest horse. The ASEAN Charter will take ASEAN through the next decades of the $21^{\text {st }}$ century. Like any other living organism, it will adapt, change and grow. Organisms only stop adapting and growing when they are dead.

Tommy Koh

Rosario G Manalo

Walter Woon 
This page intentionally left blank 


\section{Acknowledgements}

First, we would like to thank His Excellency Dr Surin Pitsuwan, Secretary-General of ASEAN, for honoring us by writing the foreword for this book.

Second, we would like to thank our fellow contributors for delivering on their commitments to write an essay each for us. This book is enriched by their insights and reflections.

Third, we would like to thank the staff of the contributors who helped in the preparation of the essays. We are grateful to Ms Chan Sze-Wei for helpfully coordinating with the many contributors. Her in-depth knowledge gained from the two years in following the process was invaluable. We appreciate the good support provided by Ms Chang Li Lin of the Institute of Policy Studies, Ms Lily Ng at the Ministry of Foreign Affairs, and Ms Juliet Lee from World Scientific Publishing. We would like to thank the Director and staff at the Institute of Policy Studies, for agreeing to co-publish this book with the World Scientific Press.

We hope that, in time, the ASEAN Charter will play a significant and positive role in the lives of the 550 million people who live in Southeast Asia.

Tommy Koh

Rosario G Manalo

Walter Woon 
This page intentionally left blank 


\section{List of Abbreviations}

ACC

ASEAN Coordinating Council

AEB

ASEAN Executive Board

AEC

ASEAN Economic Community Council

AEM

ASEAN Economic Ministers

AHRB

ASEAN Human Rights Body

AIPA

ASEAN Inter-Parliamentary Assembly

AMED

Asia-Middle East Dialogue

AMM

ASEAN Ministers' Meeting

APEC

Asia-Pacific Economic Cooperation

APSC

ASEAN Political Security Community Council

ASCC

ASEAN Socio-Cultural Community Council

ASEAN

Association of Southeast Asian Nations

ASEM

Asia-Europe Meeting

CLMV

Cambodia, Lao PDR, Myanmar and Vietnam

CPR

Committee of Permanent Representatives

DSG

Deputy Secretary-General

EDSM

Enhanced Dispute Settlement Mechanism

EPG

Eminent Persons Group 
EU

HLTF

HRB

IAMM

KL

NAM

NGO

NUS

OIC

PMC

SEANWFZ

SOM

TAC

TOR

UN

UNCTAD

UNDP

UNFPA

UNIDO
European Union

High Level Task Force

Human Rights Body

Informal ASEAN Ministerial Meeting

Kuala Lumpur

Non-Aligned Movement

Non-Governmental Organisation

National University of Singapore

Organisation of Islamic Countries

Post-Ministerial Conference

Southeast Asia Nuclear Weapons-Free Zone

Senior Officials Meeting

Treaty of Amity and Cooperation

Terms of Reference

United Nations

United Nations Conference on Trade and Development

United Nations Development Programme

United Nations Population Fund

United Nations Industrial Development Organisation

USA United States of America

VAP Vientiane Action Programme

WTO World Trade Organisation 